\title{
Towarzystwo Przyjaciół Uniejowa - 30 lat nieprzerwanej działalności na rzecz ziemi uniejowskiej
}

STRESZCZENIE | W 202I r. mija 30. rocznica powołania do życia Towarzystwa Przyjaciół Uniejowa (TPU), które funkcjonując na różnych płaszczyznach, prowadzi aktywną działalność społeczno-kulturalną na terenie gminy Uniejów.

W artykule przedstawiono okoliczności powstania TPU, jego strukturę organizacyjną oraz najistotniejsze fakty odnoszące się do historii jego funkcjonowania. Omówiono także główne kierunki działań organizacji na przestrzeni minionych trzydziestu lat.

Autorka charakteryzując dorobek towarzystwa, podjęła się w 30. rocznicę jego powstania oceny najważniejszych dokonań tej organizacji. Działalność TPU stanowi chlubną kartę w dziejach Uniejowa, a rozliczne inicjatywy podejmowane przez to stowarzyszenie sprawiają, że ma ono realny wpływ na podnoszenie jakości życia społeczno-kulturalnego mieszkańców gminy oraz przyczynia się do upamiętniania zmieniającego się obrazu miasta.

SŁOWA KLUCZOWE | kultura, społeczność lokalna, Towarzystwo Przyjaciół Uniejowa, Uniejów

\section{Geneza Towarzystwa Przyjaciół Uniejowa}

Koncepcja powołania do życia Towarzystwa Przyjaciół Uniejowa (TPU) zrodziła się na gruncie demokratycznych przemian w I990 r. Z inicjatywą wystąpili członkowie powołanego pod koniec i989 r. Społecznego Komitetu Obchodów 70o-lecia Uniejowa (tab. I). Ogromne zaangażowanie w przygotowanie i organizację obchodów zaowocowało licznymi

\footnotetext{
Agnieszka Owczarek, mgr, absolwentka Uniwersytetu im. A. Mickiewicza w Poznaniu, Instytut Filologii Romańskiej; Urząd Miasta w Uniejowie, Dział Promocji, ul. bł. Bogumiła I3, 99-2Io Uniejów; e-mail: agnieszka.owczarek@uniejow.pl
} 
wydarzeniami, które uświetniły zacną rocznicę przypadającą właśnie na rok 1990. Przedsięwzięcie zakończyło się pełnym sukcesem, a nadzwyczajne zainteresowanie mieszkańców uroczystościami unaoczniło potrzebę ożywienia kulturalnego i utwierdziło organizatorów w przekonaniu, że nie można porzucać zapoczątkowanych w czasie obchodów planów oraz pomysłów. Chęć bliższego poznania siedemsetletniej historii Uniejowa stało się inspiracją do utworzenia organizacji, która mogłaby realizować działania o charakterze społeczno-kulturalnym w długofalowej perspektywie. Jeszcze w grudniu tego samego roku, podczas spotkania podsumowującego działalność komitetu, powołano grupę inicjatywną, stanowiącą zalążek nowego stowarzyszenia. W jej składzie znaleźli się: Dariusz Piotrowski, Stanisław Urbaniak, Walenty Piotrowski, Maria Szczawińska, Danuta Pecyna, Marian Pięgot, Stefan Janiak, Lech Krajewski, Wiesław Winnicki, Jerzy Król, Henryk Prajs, Marek Jabłoński, Stanisława Kukulska, Zbigniew Włodarski, Bożena Bednarkiewicz, Wojciech Kasprzak, Maciej Gajdecki, Lech Pyziak, Jadwiga Tylki, Szymon Bugajak, Jadwiga Szymańska

Po odbyciu zebrania założycielskiego i uzyskaniu pozytywnej rekomendacji ze strony Rady Gminy i Miasta oraz Zarządu Gminy i Miasta Uniejów, 29 marca I99I r. złożono w Sądzie Wojewódzkim w Koninie wniosek o zarejestrowanie stowarzyszenia (wpis do rejestru nastąpił miesiąc później). Postanowieniem sądu z dnia 29 kwietnia 1991 r. Towarzystwo Przyjaciół Uniejowa zostało wpisane do rejestru stowarzyszeń ${ }^{2}$ i mogło oficjalnie rozpocząć swoją działalność. Dnia 3 maja, w dwusetną rocznicę uchwalenia Konstytucji 3 Maja, założyciele TPU zorganizowali we współpracy z władzami gminy Uniejów uroczystość patriotyczną. W miejscowej kolegiacie odsłonięto tablice upamiętniające dwóch obywateli Uniejowa: ks. kan. Leonarda Stawickiego, zamordowanego w Dachau, i ppłk. dr. med. Klemensa Bojakowskiego, więźnia obozu w Starobielsku, zamordowanego w Charkowie.

Dnia I5 czerwca I99I r. odbyło się walne zebranie TPU, podczas którego wybrano dziewięcioosobowy zarząd oraz trzyosobową komisję rewizyjną. Na czele zarządu stanął przewodniczący Dariusz Piotrowski. Uchwalono ponadto statut zawierający schemat organizacyjny towarzystwa oraz szczegółowo określający prawa i obowiązki jego członków, a także precyzujący

\footnotetext{
I J. Chańko, Życie kulturalne, [w:] J. Szymczak (red.), Uniejów. Dzieje miasta, Towarzystwo Przyjaciół Uniejowa, Łódź-Uniejów 1995, s. 370.

2 Tamże.
} 
zadania postawione przed stowarzyszeniem. Zgodnie ze statutem, do głównych zadań TPU miało należeć m.in.:

- prowadzenie szeroko zakrojonej działalności społeczno-kulturalnej,

- inicjowanie przedsięwzięć popularyzujących wiedzę o regionie,

- współpracowanie z władzami miasta i instytucjami społecznymi w zakresie organizowania życia społeczno-kulturalnego i gospodarczego 3 .

Walne zebranie - pierwsze $\mathrm{w}$ historii nowo powstałego towarzystwa było zwieńczeniem procedury formalnej wynikającej z ustawy o stowarzyszeniach, a jednocześnie początkiem ożywionej, wielokierunkowej działalności tej organizacji. Uroczystość, którą można nazwać inaugurującą, zorganizowano 2I września 199I r. przy okazji uczczenia obchodów wybuchu drugiej wojny światowej. Tego dnia w Miejsko-Gminnym Ośrodku Kultury w Uniejowie dwudziestu czterech członków otrzymało legitymacje członkowskie i znaczki TPU. Padła też propozycja utworzenia izby pamiątek o Uniejowie. Następnie złożono kwiaty pod pomnikiem na rynku w asyście Orkiestry Reprezentacyjnej Pomorskiego Okręgu Wojskowego i przemaszerowano na parking obok zamku, gdzie odbyły się pokaz musztry paradnej oraz koncert ${ }^{4}$. To wydarzenie, pierwsze pod względem chronologicznym, dało efekt śnieżnej kuli, zapoczątkowując szereg tego rodzaju wydarzeń, które miały miejsce na przestrzeni lat.

Towarzystwo Przyjaciół Uniejowa długo nie posiadało swojej siedziby. Na potrzeby prowadzenia działalności korzystało z udostępnionego pomieszczenia przy schodach paradnych w zamku, które członkowie TPU zaadaptowali i wyposażyli własnym sumptem. Po trzech latach wciąż nieoficjalną siedzibą organizacji był Miejsko-Gminny Ośrodek Kultury w Uniejowie. Dopiero w 2006 r. po uzyskaniu akceptacji i pomocy finansowej ze strony burmistrza Józefa Kaczmarka oraz samorządu Uniejowa, a także dzięki wsparciu od miejscowych przedsiębiorców udało się wyremontować budynek przy ul. Szkolnej 2, który przeznaczono na siedzibę towarzystwa oraz Izbę Regionalną Ziemi Uniejowskiej otwartą uroczyście w 2007 r.5

W Izbie Regionalnej gromadzone są pamiątki, fotografie, dokumenty oraz wspomnienia, uratowane niejednokrotnie przed zniszczeniem i trafieniem na śmietnik. Dzięki pokaźnej i ustawicznie powiększającej się kolekcji

3 Towarzystwo Przyjaciół Uniejowa, [w:] Kronika TPU I990, t. I, s. 5.

4 Powstanie Towarzystwa Przyjaciót Uniejowa i jego pierwsze działania, [w:] 25 lat Towarzystwa Przyjaciót Uniejowa I99I-20I6, s. 7.

5 Tamże, s. 19. 
stała się ona miejscem lekcji historii, odwiedzanym przez dzieci, młodzież oraz dorosłą społeczność gminy Uniejów. W 2012 r. w ramach programu "Wdrażanie lokalnych strategii rozwoju”, objętego PROW na lata 2007-2013, jak również dzięki wsparciu Urzędu Miasta w Uniejowie, zrealizowano projekt remontu kolejnego pomieszczenia, które zostało zaadaptowane na Salę Wystawową. Odbywają się w niej rozliczne wydarzenia kulturalne, okolicznościowe wystawy czy spotkania rocznicowe. Miejsce to stało się ważnym punktem kulturalnym na mapie Uniejowa ${ }^{6}$.

Tabela I. Kalendarium wydarzeń dotyczących początków istnienia i działalności Towarzystwa Przyjaciół Uniejowa

\begin{tabular}{|c|c|c|}
\hline Data & Miejsce & Wydarzenie \\
\hline 29 grudnia $1989 \mathrm{r}$. & Uniejów & $\begin{array}{c}\text { Podczas IX sesji Rady Narodowej Miasta } \\
\text { i Gminy w Uniejowie na wniosek } \\
\text { Przewodniczącego Rady Stanisława } \\
\text { Urbaniaka oraz Naczelnika Miasta i Gminy } \\
\text { Uniejów Stefana Janiaka podjęto uchwałę } \\
\text { w sprawie obchodów 7oo-lecia Uniejowa }\end{array}$ \\
\hline 27 grudnia I990 r. & Uniejów & Powołanie grupy inicjatywnej \\
\hline 29 kwietnia I99I r. & Konin & $\begin{array}{l}\text { Zarejestrowanie towarzystwa } \\
\text { przez Sąd Wojewódzki w Koninie }\end{array}$ \\
\hline I5 czerwca I99I r. & Uniejów & $\begin{array}{c}\text { Zebranie walne, } \\
\text { wybór dziewięcioosobowego zarządu }\end{array}$ \\
\hline
\end{tabular}

Źródło: opracowanie własne na podstawie wydania specjalnego kwartalnika „W Uniejowie” - 25 lat Towarzystwa Przyjaciół Uniejowa 1991-2016

\section{Władze i struktura organizacyjna Towarzystwa Przyjaciół Uniejowa}

Zgodnie ze statutem władzę w towarzystwie sprawują trzy organy: walne zebranie, zarząd oraz komisja rewizyjna. Najwyższą instancją jest walne zebranie, a więc władza uchwałodawcza, która obraduje raz w roku jako zebranie sprawozdawcze i co cztery lata jako zebranie sprawozdawczo-wyborcze. Do jego kompetencji należy m.in. wybór oraz odwoływanie prezesa i pozostałych członków zarządu i komisji rewizyjnej, składanie sprawozdań oraz

6 Lata 20II-20I5, dz. cyt., s. I6. 
dokonywanie oceny realizacji wyznaczonych zadań, określanie programu działalności, podejmowanie uchwał i wprowadzanie zmian w statucie, a także ustalanie wysokości składek7.

Analiza dotychczasowego przebiegu prac towarzystwa, również pod względem wypełniania obowiązków sprawozdawczych, pozwala wysunąć wniosek, że działało ono harmonijnie, sprawnie, transparentnie i bez zakłóceń.

Statut dopuszcza ponadto możliwość zwołania tzw. walnego zebrania nadzwyczajnego. W dotychczasowej historii TPU tylko raz zaistniała potrzeba zwołania tego typu obrad. Podjęto podczas nich decyzję o ubieganie się o status organizacji pożytku publicznego. Uzyskanie statutu OPP, co miało miejsce w kwietniu 2010 r., otworzyło nowy rozdział w historii działalności TPU, przede wszystkim stało się istotną determinantą z punktu widzenia rozwoju strategii i funkcjonowania organizacji. Umożliwiło to m.in. uruchomienie mechanizmu I proc. Status ten okazał się także niezwykle pomocny w kontekście pozyskiwania funduszy na realizację projektów ${ }^{8}$. Z perspektywy 30 lat działalności walne zebranie nadzwyczajne wydaje się więc być szczególnie istotne w historii organizacji. Drugim przełomowym zebraniem było to z czerwca I99I $r$. W jego wyniku, jak już wzmiankowano, Towarzystwo rozpoczęło działalność na rzecz gminy Uniejów.

\section{Zarząd Towarzystwa Przyjaciół Uniejowa}

Zarząd towarzystwa składa się z 7-9 osób: prezesa, dwóch wiceprezesów, sekretarza, skarbnika oraz 2-4 członków zarządu. Do jego kompetencji należy koordynowanie pracami towarzystwa, realizowanie uchwał walnego zebrania oraz przyjętego programu działania, gospodarowanie funduszami organizacji i reprezentowanie towarzystwa na zewnątrz. Dostrzega się korelację pomiędzy poziomem efektywności i sprawnego codziennego funkcjonowania całego towarzystwa a aktywnością i zaangażowaniem prezesa i członków zarządu. To właśnie na władzach spoczywa obowiązek podejmowania inicjatyw umożliwiających realizację postawionych celów.

7 Statut Towarzystwa Przyjaciót Uniejowa, art. 4, Władze i struktura organizacyjna (tekst sporządzony przez zarząd Towarzystwa Przyjaciół Uniejowa z uwzględnieniem zmian przyjętych podczas walnego zebrania członków w dniu I7 marca 2018 r.).

8 Poradnik - przywileje OPP, [online] http://www.poradnik.ngo.pl/przywileje-opp [dostęp: 10.05.202I]. 
Pierwszym prezesem towarzystwa był Dariusz Piotrowski (ryc. I), który pełnił tę funkcję przez dwie kadencje - do 1999 r. Zastąpiła go na tym stanowisku Urszula Urbaniak, która piastuje ten urząd do dziś. Zachowanie stanowiska przez ponad dwadzieścia lat dobitnie świadczy o tym, jak wysoko cenione są kompetencje merytoryczne pani Urszuli Urbaniak oraz sposób kierowania pracami zarządu. Pozostali członkowie zarządu również nie raz odnawiali swój mandat społeczny w kolejnych kadencjach, co także dowodzi zaufania ze strony pozostałych działaczy oraz akceptacji dla obranego sposobu zarządzania. Być może właśnie owa niezmienność w kierownictwie TPU stała się gwarantem stabilizacji pozwalającej uniknąć potencjalnych komplikacji i zawirowań.

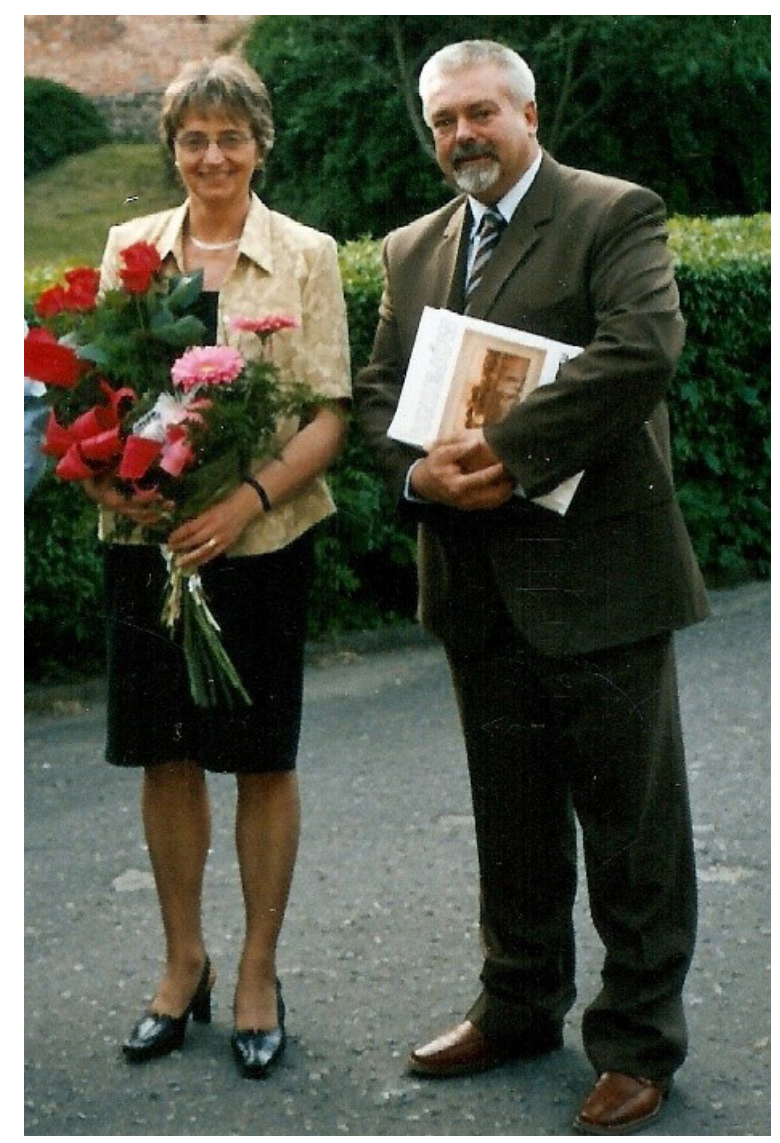

Ryc. I. Pierwszy prezes TPU - Dariusz Piotrowski, i obecna prezes Urszula Urbaniak w dniu promocji albumu Uniejów. Dotyk Czasu

Źródło: Urząd Miasta w Uniejowie 
Poniżej przedstawiono zestawienie składu osobowego zarządu TPU w poszczególnych kadencjach:

Zarząd Towarzystwa Przyjaciół Uniejowa (I5.06.199I r. - 29.05.1999 r.)

Prezes - Dariusz Piotrowski

Wiceprezesi - Stanisław Urbaniak, Jadwiga Szymańska

Skarbnik - Bożena Bednarkiewicz

Sekretarz - Maria Szczawińska

Członkowie - Marek Jabłoński, Lech Krajewski, Józef Rafalski, Andrzej Urbaniak

Zarząd Towarzystwa Przyjaciół Uniejowa (29.05.1999 r.-21.06.2003 r.)

Prezes - Urszula Urbaniak

Wiceprezesi - Barbara Pastorczak, Henryk Pęcherski

Skarbnik - Bożena Bednarkiewicz

Sekretarz - Maria Szczawińska

Członkowie - Janina Janczak Kaszyńska, Mirosław Sobieraj, Jadwiga Szymańska, Ryszard Troczyński

Zarząd Towarzystwa Przyjaciół Uniejowa (21.06.2003 r. - I6.06.2007 r.)

Prezes - Urszula Urbaniak

Wiceprezesi - Bożena Bednarkiewicz, Małgorzata Charuba

Skarbnik - Mirosław Sobieraj

Sekretarz - Maria Szczawińska

Członkowie - Jadwiga Szymańska, Ryszard Troczyński

Zarząd Towarzystwa Przyjaciół Uniejowa (I6.06.2007 r. - 26.03.20I I r.)

Prezes - Urszula Urbaniak

Wiceprezesi - Bożena Bednarkiewicz, Małgorzata Charuba,

Skarbnik - Mirosław Sobieraj, Jadwiga Tylki

Sekretarz - Maria Szczawińska

Członkowie - Jadwiga Tylki, Mirosław Sobieraj, Andrzej Urbaniak

Zarząd Towarzystwa Przyjaciół Uniejowa (26.03.20I I r. - I4.03.20I5 r.)

Prezes - Urszula Urbaniak

Wiceprezesi - Małgorzata Charuba, Jerzy Król

Skarbnik - Jadwiga Tylki 
Sekretarz - Maria Szczawińska

Członkowie - Joanna Wicherkiewicz, Barbara Zwolińska

Zarząd Towarzystwa Przyjaciół Uniejowa (I4.03.20I5 r. - 23.03.2019 r.)

Prezes - Urszula Urbaniak

Wiceprezesi - Małgorzata Charuba, Jerzy Król

Skarbnik - Jadwiga Tylki

Sekretarz - Maria Szczawińska

Członkowie - Arleta Ciepłuch-Becalik, Ryszard Troczyński, Joanna Wicherkiewicz

Od 23 marca 2019 r.

Prezes - Urszula Urbaniak

Wiceprezes - Małgorzata Charuba, Joanna Wicherkiewicz

Skarbnik - Jadwiga Tylki

Sekretarz - Maria Szczawińska

Członkowie - Joanna Pawlak, Janina Król

Źródło: opracowanie własne na podstawie wydania specjalnego kwartalnika „W Uniejowie” - 25 lat Towarzystwa Przyjaciół Uniejowa I99I-20I6

\section{Komisja Rewizyjna Towarzystwa Przyjaciół Uniejowa}

Kolejnym organem ustanowionym przez statut jest komisja rewizyjna. W zakres jej obowiązków wchodzi: regularna kontrola całokształtu działalności towarzystwa i jego gospodarki finansowej oraz składanie sprawozdań podczas obrad walnego zebrania towarzystwa wraz z oceną i wnioskami dotyczącymi udzielenia (lub nieudzielenia) absolutorium ustępującemu zarządowi towarzystwa9 ${ }^{9}$. Komisja Rewizyjna w ramach swoich uprawnień pełni funkcję kontrolną nad pracami zarządu, odgrywając tym samym istotną rolę w kontekście całościowego funkcjonowania towarzystwa. Skład tej komisji w poszczególnych kadencjach działalności TPU przedstawiono w tab. 2 .

9 Tamże. 
Tabela 2. Składy komisji rewizyjnej w kolejnych kadencjach

\begin{tabular}{|c|c|c|}
\hline Kadencja & Przewodniczący & Członkowie \\
\hline I99I-I999 & Stefan Janiak & Jadwiga Tylki, Lech Pyziak \\
\hline $1999^{-2003}$ & Tomasz Kałużny & Barbara Jagieła, Jan Górczyński \\
\hline $2003-2007$ & Tomasz Kałużny & Barbara Kozanecka, Janusz Stawicki \\
\hline $2007^{-20 I I}$ & Janusz Stawicki & Jerzy Król, Jadwiga Szymańska \\
\hline $2011-2015$ & Lech Krajewski & Jadwiga Broż, Jadwiga Szymańska \\
\hline $2015^{-2019}$ & Lech Krajewski & Jadwiga Broż, Henryka Marciniak \\
\hline $2019-2023$ & Lech Krajewski & $\begin{array}{c}\text { Arleta Ciepłuch-Becalik, } \\
\text { Henryka Marciniak }\end{array}$ \\
\hline
\end{tabular}

Źródło: Opracowanie własne na podstawie wydania specjalnego kwartalnika „W Uniejowie” - 25 lat Towarzystwa Przyjaciół Uniejowa I99I-2016

\section{Członkowie Towarzystwa Przyjaciół Uniejowa}

Niewątpliwie filarem towarzystwa są ludzie, a więc jego członkowie. To oni poprzez swoje zaangażowanie, pasję i wspólną pracę sprawiają, że wszelkie przedsięwzięcia stają się możliwe do zrealizowania. Skład osobowy Towarzystwa Przyjaciół Uniejowa od zawsze cechował się pewną wyjątkowością. W jego szeregach znaleźli się naukowcy reprezentujący niemal wszystkie dziedziny nauk humanistycznych, bibliotekarze, artyści, literaci, a także pracownicy instytucji kulturalnych i działacze kultury, nauczyciele oraz dziennikarze prasy lokalnej. Rekrutowali się oni głównie spośród mieszkańców Uniejowa i okolic - wszyscy złączeni wspólną pasją do małej ojczyzny (ryc. 2).

Stan osobowy towarzystwa jest płynny, ale biorąc pod uwagę dostępne dane dotyczące jego liczebności, można szacunkowo przyjąć, że przez minione 30 lat organizacja zgromadziła łącznie około 200 osób. Lista członków z 1995 r. zawiera 53 nazwiska, a od 2000 r. liczba działaczy wynosiła zawsze około I20 osób. Na przestrzeni 30 lat zmarło 48 osób. Obecny stan to Io8 członków, w tym 36 zamieszkałych poza gminą Uniejów ${ }^{\text {I0 }}$. Sympatyków TPU trudno zliczyć, niemało jest także osób utrzymujących stały kontakt z towarzystwem, a nieposiadających statusu członka. Towarzystwo zatem

IO 30 lat minęto - Jubileusz Towarzystwa Przyjaciót Uniejowa, „W Uniejowie” 202I, nr 85 , s. 19 . 
wciąż się rozwija, niczym żywy organizm. W poczet członków zwyczajnych TPU mogą zostać przyjęte osoby, które deklarują swoje przystąpienie do towarzystwa i są gotowe brać czynny udział w realizacji jego celów statutowych, innymi słowy każdy, kto traktuje ziemię uniejowską jak swoją małą ojczyznę i stara się włączać w inicjatywy służące jej rozwojowi. Osoby szczególnie zasłużone dla rozwoju miasta i gminy Uniejów mogą otrzymać od towarzystwa odznaczenie w formie tzw. członkostwa honorowego, które przyznawane jest w trakcie walnego zebrania na wniosek zarządu. Od początku istnienia do 202I r. jedynym członkiem honorowym była Jadwiga Kwaśnowa-Kwaszewska - pierwsza powojenna kierowniczka Szkoły Podstawowej w Uniejowie, której odznaczenie wręczono „w uznaniu dla szczególnych zasług na rzecz kultury, oświaty oraz za znaczący wkład przy organizacji obchodów 70o-lecia Uniejowa”. Podczas ostatniego walnego zebrania, odbywającego się 4 czerwca 202I r., tytuł honorowego członka TPU przyznano Lucjanowi Józefowiczowi, który przez wiele lat był członkiem zwyczajnym towarzystwa. Ten rodowity uniejowianin zapisał się w historii polskiego kolarstwa jako jeden z najlepszych kolarzy torowych. Był także wielokrotnym mistrzem Polski, uczestnikiem mistrzostw świata oraz olimpijczykiem z Tokio z I964 r. W uznaniu dla jego osiągnięć, dzięki którym wpisał się w poczet sławnych uniejowian, dołączył do grona członków honorowych.

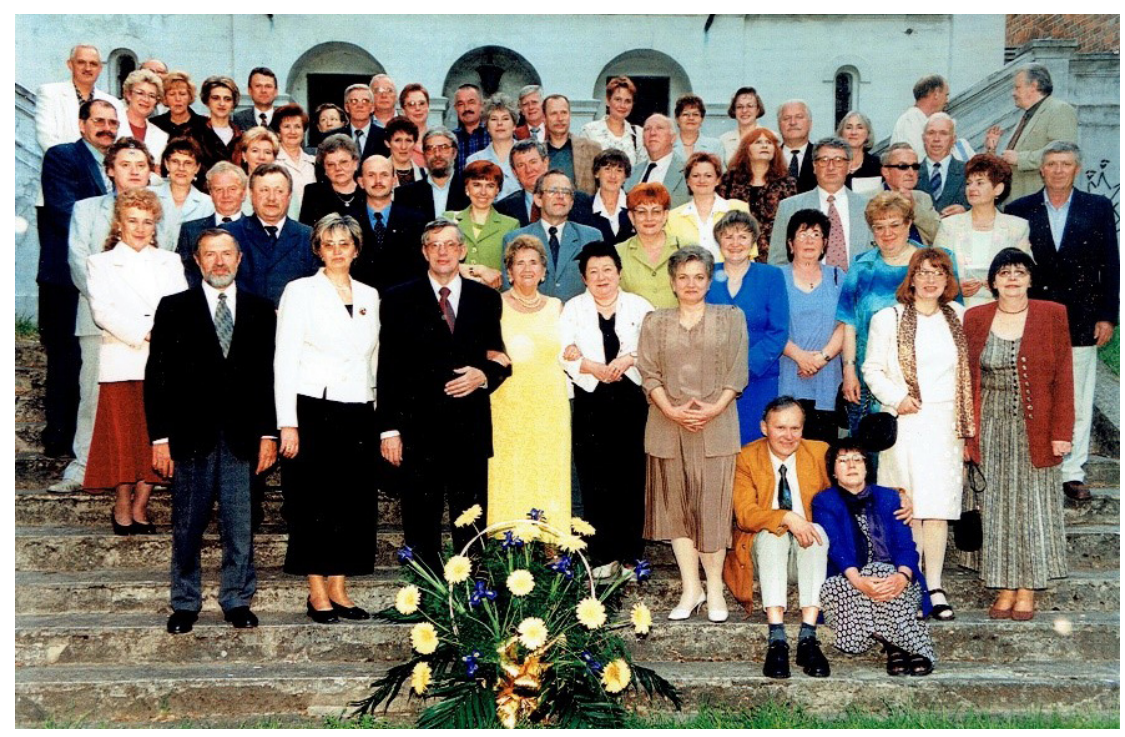

Ryc. 2. Członkowie TPU w dniu obchodów Io. rocznicy powstania organizacji Źródło: Archiwum TPU 


\section{Retrospekcja z trzydziestoletniej działalności Towarzystwa Przyjaciół Uniejowa}

Towarzystwo Przyjaciół Uniejowa prowadzi od początku funkcjonowania intensywną działalność społeczno-kulturalną. Obecny statut, który kilkakrotnie był nowelizowany, zawiera znacznie więcej założeń niż trzy główne cele, które do niego wpisano, gdy organizacja powstawała. Ewolucja programowa to efekt zmian zachodzących w społeczności lokalnej oraz nowej sytuacji gospodarczej w kraju, mieście czy regionie. Niektóre cele zależne są też od aktualnych wymogów bądź potrzeb społecznych. Należą do nich:

- realizowanie zadań związanych z edukacją ekologiczną ze szczególnym uwzględnieniem promocji miasta i gminy Uniejów oraz walorów środowiskowych regionu;

- promowanie i wspieranie uzdolnionej młodzieży w rozwijaniu ich zainteresowań;

- działania na rzecz integracji europejskiej oraz rozwijania kontaktów i współpracy między społeczeństwami;

- wyrównywanie szans edukacyjnych dzieci i młodzieży ze środowisk wiejskich;

- podejmowanie działań w zakresie edukacji regionalnej i historycznej, służącej podtrzymywaniu tradycji narodowej, pielęgnowaniu polskości oraz rozwojowi świadomości narodowej, obywatelskiej i kulturowej;

- promocja i organizacja wolontariatu;

- działania na rzecz rozwoju krajoznawstwa i turystyki w regionie;

- realizowanie zadań z zakresu edukacji ustawicznej skierowanej do osób dorosłych, w tym seniorów i osób starszych, oraz aktywizowanie osób dorosłych, w tym seniorów i osób starszych, poprzez ich uczestnictwo w różnych formach życia społecznego ${ }^{\mathrm{II}}$.

Program działania towarzystwa, upraszczając zagadnienie, sprowadza się do upowszechniania i gromadzenia wiedzy historycznej, upamiętniania ważnych wydarzeń i osób zasłużonych dla regionu, promocji miasta i gminy Uniejów oraz budowania oferty kulturalnej dla mieszkańców. Założenia realizowane są we współpracy z władzami lokalnymi, instytucjami kultury i z udziałem oraz dzięki zaangażowaniu samych mieszkańców. Warto w tym miejscu zastanowić się, na ile wyznaczone przez towarzystwo

II Towarzystwo Przyjaciót Uniejowa, [online] http://www.rejestr.io/krs/25038o/towarzystwo-przyjaciol-uniejow [dostęp: I0.05.202I]. 
cele zostały zrealizowane. Posłuży do tego analiza dorobku Towarzystwa Przyjaciół Uniejowa i omówienie najważniejszych obszarów działalności prowadzonej w celu zaspokojenia społecznych, kulturalnych i edukacyjnych potrzeb mieszkańców.

\section{Dziatalność na rzecz kultury}

Jedną z najważniejszych sfer działalności towarzystwa jest niewątpliwie wkład w życie społeczno-kulturalne regionu. W celu wzbogacenia oferty kulturalnej Uniejowa TPU organizuje sesje popularnonaukowe o tematyce interesującej mieszkańców, wieczory artystyczne, podczas których promowana jest twórczość lokalnych pisarzy i poetów, przygotowuje wystawy, koncerty kameralne i recitale. Organizowane są ponadto następujące spotkania cykliczne: Zwyczajni a Niezwykli, Ludzie z pasja, Młodzi zdolni stąd, Moje podróże mate i duże.

Nie sposób wymienić w niniejszym artykule wszystkich inicjatyw podejmowanych przez Towarzystwo Przyjaciół Uniejowa w ciągu minionych 30 lat, jednak kilka z nich bez wątpienia zasługuje na wyróżnienie. Do takich przedsięwzięć należała inicjatywa i sama organizacja Dni Uniejowa, które po raz pierwszy zostały przygotowane wspólnie z Urzędem Miasta w 1992 r.

W programie pierwszych obchodów święta miasta znalazły się m.in. loty samolotowe nad miastem, pokazy skoków spadochronowych, wystawa malarska Zbigniewa Marjanowskiego, program kabaretowy oraz imprezy sportowe. W specjalnym wydaniu czasopisma „W Uniejowie” tak wspominano te wydarzenia:

Iskra, którą wtedy rozpalono w sercach mieszkańców, by mogli dostrzec i wspólnie cieszyć się pięknem swojej małej ojczyzny, z każdym rokiem płonęła odważniej, by w momencie kiedy pozwoliły na to okoliczności, odpalić lont kolorowych fajerwerków, które rokrocznie rozświetlają niebo podczas finału tego wspaniałego uniejowskiego święta ${ }^{12}$.

Zarząd towarzystwa systematycznie wspierał też finansowo imprezy szkolne, kulturalne i sportowe, m.in.: 20 lat nadania SP w Uniejowie imienia i sztandaru, 20 lat powstania MGOK w Uniejowie, I20 lat powstania

I2 J. Kaczmarek, Drodzy Przyjaciele..., [w:] 2s lat Towarzystwa Przyjaciót Uniejowa I99I-20I6, s. 4 . 
uniejowskiej OSP, międzywojewódzkie szkolne turnieje piłki nożnej, sympozja naukowe i konkursy plastyczne. Był fundatorem nagród w przeglądach orkiestr strażackich oraz corocznych nagród dla najlepszych absolwentów oraz laureatów konkursów przedmiotowych w SP w Uniejowie. Nieodpłatnie przekazał na promocję miasta wiele monografii, widokówek i okolicznościowych medali. Udzielił też wsparcia finansowego na remont kolegiaty oraz sfinansował lampę oświetleniową na uniejowskim rynku.

Członkowie TPU aktywnie uczestniczą w organizowaniu imprez rocznicowych, zachęcając do szukania i utrwalania śladów historii i kultury na terenie miasta i gminy Uniejów. Przez cały okres swojego istnienia towarzystwo poprzez liczne inicjatywy bierze udział w procesie kształtowania kulturalnego oblicza Uniejowa, aktywizując i integrując lokalne środowisko i wspierając budowanie świadomości obywatelskiej. W kolejnych latach funkcjonowania towarzystwa można zaobserwować doskonalenie jego metod i form pracy.

Podejmowane przez tę organizację działania często wykraczają poza ramy nakreślone w statucie. To efekt silnej identyfikacji z lokalną społecznością, zaangażowania w jej sprawy oraz aktywizowania środowiska mieszkańców poprzez rozbudzanie w nich zainteresowania historią miejsca ich urodzenia i zamieszkania.

TPU było wreszcie inicjatorem powstania uniejowskiego Uniwersytetu Trzeciego Wieku. W 2013 r. powołano grupę inicjatywną ${ }^{13}$ i powierzono jej misję utworzenia UTW. Przedsięwzięcie poparł burmistrz Józef Kaczmarek, podkreślając, że udział seniorów w tego typu zajęciach to okazja do realizowania swoich marzeń w świecie rozlegle pojętej wiedzy, kultury i sztuki poprzez rozwijanie aktywności intelektualnej i zawodowej oraz doskonalenie swych uzdolnień i rozwijanie pasji.

Grupa inicjatywna nawiązała kontakty z uniwersytetami działającymi już na terenie woj. łódzkiego i we wrześniu 2013 r. we współpracy z Akademią Inicjatyw Społecznych z Łodzi zorganizowała w Uniejowie konferencję w ramach projektu „Seniorze, angażuj się w zmiany”, w której udział wzięli m.in.: liderzy UTW z Łasku, Tomaszowa Mazowieckiego, Zgierza, Opoczna, Dmosina i Uniejowa. Kilka miesięcy później, w styczniu 2014 r., zorganizowano w Miejsko-Gminnym Ośrodku Kultury pierwsze spotkanie

I3 Skład grupy inicjatywnej: Teresa Łuczak, Krystyna Kowalczyk, Jerzy Król, Danuta Pecyna, Urszula Urbaniak. 
informacyjne, na którym przedstawiono zarys działania UTW i rozdano deklaracje. W dniu 27 stycznia 2014 r. odbyło się I Walne Zebranie Słuchaczy, podczas którego przyjęto regulaminy wewnętrzne oraz wybrano zarząd i prezesa - Urszulę Urbaniak. Słuchaczem mogła być osoba po ukończeniu 55 roku życia, mieszkająca na obszarze gm. Uniejów i innych miejscowości z nią sąsiadującymi. Uniejowski UTW, powstały jako sekcja Miejsko-Gminnego Ośrodka Kultury, wspierany organizacyjnie przez Towarzystwo Przyjaciół Uniejowa, rozpoczął działalność od II semestru roku akademickiego 2013/20I4 i był wówczas 29. UTW zarejestrowanym na terenie woj. łódzkiego.

\section{Miejsca pamięci i działalność kronikarska}

Towarzystwo nieustannie gromadzi dokumenty, fotografie, spisuje także wspomnienia świadków wojennych, było i jest inicjatorem oraz organizatorem inicjatyw związanych z przywróceniem prawdy historycznej o zbrodni katyńskiej. Efekt tych działań stanowi utworzenie nowego miejsca pamięci - Placu Dębów Katyńskich. W kwietniu 2008 r. TPU przystąpiło do ogólnopolskiej akcji „Katyń... ocalić od zapomnienia”, w ramach której posadzono Dęby Pamięci. Każde posadzone drzewo upamiętnia konkretną osobę - ofiarę zbrodni katyńskiej, związaną z gminą Uniejów. Członkowie TPU przygotowali także projekt edukacyjny pt. „Katyń - pamięć ocalona”, który zakładał m.in. współpracę z młodzieżą z Gimnazjum w Uniejowie w pozyskiwaniu informacji oraz zgłębianiu wiedzy historycznej na temat wydarzeń związanych ze zbrodnią katyńską oraz wojennych losów mieszkańców gminy i powiatu poddębickiego. Zintegrowanie młodszego i starszego pokolenia pozwoliło sięgnąc do lokalnej tradycji nawiązującej do pamięci o patriotycznych wydarzeniach z przeszłości.

W nowym miejscu pamięci, które Uniejów zyskał dzięki wspólnym działaniom koordynowanym przez towarzystwo, pierwsze dęby posadzono I7 września 2009 r. W 2010 r. w 70. rocznicę mordu katyńskiego odsłonięto podczas powiatowej uroczystości patriotyczno-religijnej pomnik. Od tego czasu każdego roku dnia I3 kwietnia na Placu Dębów Katyńskich akcentowane są obchody Dnia Pamięci Ofiar Zbrodni Katyńskiej z udziałem młodzieży szkolnej, członków rodzin pomordowanych, przedstawicieli władz samorządowych, księży oraz mieszkańców. 
Pisząc o miejscach pamięci, nie sposób pominąć Izby Regionalnej Ziemi Uniejowskiej, w której gromadzone są liczne pamiątki i dokumenty dotyczące historii miasta i okolic, począwszy od I836 r. aż po czasy współczesne. W zbiorach znajdują się m.in. akta uniejowskiego koła Związku Kombatantów RP i Byłych Więźniów Politycznych, stanowiące spuściznę po ważnych postaciach dla lokalnej społeczności, oraz materiały dotyczące różnych aspektów przeszłości Uniejowa (cechy, parafia, szkoły). Archiwalia utworzone są z materiałów uzyskanych w ramach projektów realizowanych przez towarzystwo lub przekazywanych ze zbiorów prywatnych w formie darowizny ${ }^{\mathrm{I}}$. Izba Regionalna to także miejsce spotkań o charakterze wspomnieniowym, zwłaszcza ze świadkami wojennych wydarzeń i lat okupacji.

Poprzez takie działania towarzystwo nie tylko realizuje cele statutowe związane z dbałością o lokalny dorobek kulturowy, ale daje też świadectwo pamięci i uświadamia młodemu pokoleniu, że kultywowanie tradycji i pielęgnowanie ołtarzy przeszłości jest kluczem do budowania przyszłości i kształtowania postawy młodego pokolenia.

\section{Publikacje}

Jedną z niezwykle ważnych sfer aktywności towarzystwa jest działalność wydawnicza. Szczególną rolę w promowaniu ziemi uniejowskiej odgrywa kwartalnik „W Uniejowie”, który ukazuje się systematycznie od 2000 r. i jest organem prasowym towarzystwa. Od początku istnienia TPU postawiło sobie za cel wydawanie lokalnej gazety, która oprócz bieżących informacji mogłaby odkrywać karty historii Uniejowa. Okazja pojawiła się w 1993 r. w trakcie obchodów Dni Uniejowa. Ukazało się wówczas pierwsze wydanie specjalne, określane potocznie mianem żółtej kserówki, tekst spisano bowiem na maszynie do pisania z powielaczem bez udziału komputera i innych zdobyczy technologii, natomiast odbitki wykonano za pomocą czarno-białej kserokopiarki.

TPU zaznaczyło swoją obecność w uniejowskiej społeczności, a broszura stała się zaczątkiem systematycznej działalności wydawniczej, którą urzeczywistniono kilka lat później. Od wydania pierwszego regularnego

I4 U. Urbaniak, Izba Regionalna Ziemi Uniejowskiej, [online] Towarzystwo Przyjaciół Uniejowa https://archiwa.org [dostęp: I0.05.202I]. 
numeru, który ukazał się w 2000 r., periodyk przeszedł całkowitą metamorfozę, zarówno pod kątem szaty graficznej, jak i prezentowanych treści. Zmiana podyktowana była pojawieniem się w marcu 2004 r. konkurencyjnej pozycji wydawniczej na rynku prasy lokalnej, publikowanej przez Urząd Miasta w Uniejowie. Dwumiesięcznik „Uniejowskie Strony” jako periodyk samorządowy adresowany do mieszkańców gminy dostarcza informacji na temat bieżących wydarzeń dotyczących lokalnego rozwoju, kultury i oświaty. W zaistniałej sytuacji zespół redakcyjny TPU szukał sposobu, dzięki któremu udałoby się zachować indywidualny charakter kwartalnika, ale i poczytność gazety. Rozwiązaniem okazała się historia.

Chociaż kwartalnik „W Uniejowie” to czasopismo interdyscyplinarne, dostarczające wiedzy na temat wydarzeń społecznych, gospodarczych i kulturalnych, na łamach którego zamieszczane są artykuły, reportaże, relacje z imprez, wywiady, sprawozdania, ogłoszenia, informacje z życia szkół czy dotyczące sportowców, strażaków, rolników, kombatantów, emerytów, parafii, to jego niewątpliwym wyróżnikiem jest ukierunkowanie historyczne i pisarstwo wspomnieniowe. Pod tym względem gazeta stanowi cenne źródło informacji, chociażby dlatego, że część opisywanych zakładów już nie istnieje, a wiele prezentowanych miejsc przeszło radykalną metamorfozę. W kwartalniku przedstawiane są sylwetki osób, które z pasją i zaangażowaniem przyczyniają się do rozwoju lokalnej społeczności i mikroregionu, a fotografie, zarówno współczesne, jak i archiwalne, redaktorzy opisują z wielką pieczołowitością, próbując zatrzymać czas i uchronić mieszkańców od zapomnienia.

Obecny kształt kwartalnika to wynik pracy zespołu redakcyjnego oraz zaangażowania czytelników. Funkcję redaktora naczelnego pełni Andrzej Zwoliński, a za finalną postać pisma odpowiada prezes TPU Urszula Urbaniak przy ścisłej współpracy wiceprezes Małgorzaty Charuby. Wcześniej redaktorami naczelnymi byli Barbara Pastorczak i Tomasz Wójcik.

Możliwość wydawania pisma przez ponad dwadzieścia lat TPU zawdzięcza władzom samorządowym, które wspierają wszelkie działania promocyjne i dostrzegają pozytywną rolę mediów w kreowaniu wizerunku gminy. Aktywność wydawnicza, która wyznacza pewien stały rytm pracy towarzystwa, nie ogranicza się jedynie do wspomnianego kwartalnika.

W 1993 r. TPU wystąpiło z inicjatywą przygotowania monografii Uniejowa przez Łódzki Oddział Polskiego Towarzystwa Historycznego, chociaż pomysł na tego rodzaju przedsięwzięcie zakiełkował przy okazji 
wspomnianych już obchodów 700-lecia Nadania Praw Miejskich Uniejowowi ${ }^{15}$. Opracowanie monografii zakończyło się sukcesem. Dwa lata później światło dzienne ujrzała książka Uniejów. Dzieje miasta, wydana pod red. profesora Jana Szymczaka.

Jako suplementy do monografii ukazały się także dwie pozycje biograficzne: Ksiądz Wtadystaw Góra (200I) i Ksiądz Stanistaw Smolarski (2003). W maju 2003 r. TPU wydało album fotograficzny W stronę Uniejowa ${ }^{16}$. Rok później w ramach projektu „Uniejowskie ślady, póki jeszcze ktoś pamięta” ukazał się album starej fotografii pt. Uniejów. Dotyk czasu. Publikacja stanowi obszerny zbiór fotografii, powstały w odpowiedzi na apel o udostępnienie pamiątek $\mathrm{z}$ domowych archiwów. Każda kolejna strona to podróż sentymentalna po ulicach i miejscach, które dziś wyglądają zupełnie inaczej, ale również nostalgiczne spotkania z osobami, które już odeszły. Album powstał w ważnym momencie dziejowym dla kraju - u progu wstąpienia Polski do Unii Europejskiej. Towarzystwo poprzez tego rodzaju publikację chciało dać wyraz swojemu zaangażowaniu w budowanie przyszłości w europejskiej wspólnocie, wnosząc do niej własną tożsamość w postaci fascynującej historii oraz rodzimej kultury i tradycji.

Następne lata działalności TPU zaowocowały kolejnymi publikacjami. W 2005 r. na wystawie pt. „80 lat kultu bł. Bogumiła”, zorganizowanej w kolegiacie, towarzystwo zaprezentowało swoje zbiory dotyczące postaci arcybiskupa Bogumiła, na podstawie których powstało kilka publikacji: Opowieść o bt. Bogumile autorstwa Adama Zdzisława Józefowicza (2006), broszura $\mathrm{Ku}$ czci św. Bogumita - wybór pieśni i modlitw (2007) i Rozśpiewały się dzwony i serca ludzi - praca zbiorowa pod redakcją Andrzeja Urbaniaka (2008) ${ }^{\text {r7 }}$.

W 70. rocznicę zbrodni katyńskiej wydano również książkę Tam zostali. Z ziemi uniejowskiej, z ziemi poddębickiej, w której zamieszczono biogramy ofiar katyńskich ze wszystkich gmin powiatu poddębickiego. Powstanie tej pozycji książkowej związane było ze wspomnianą już ogólnopolską akcją upamiętniającą zbrodnię katyńską. Fragmenty materiałów ukazywały się wcześniej na łamach „W Uniejowie” jako dodatek specjalny do kwartalnika ze wspomnieniami rodzin katyńskich. Na podobnej zasadzie drukowano historie losów wojennych mieszkańców, które stały się zalążkiem publikacji

\footnotetext{
Is A.R. Tyczyno, roo lat budowania społeczeństwa obywatelskiego na Ziemi Uniejowskiej, Urząd Miasta w Uniejowie, Uniejów 2013, s. 89.

I6 Tamże, s. 89.

I7 Tamże, s. 89.
} 
Zapamiętane z Brückstadt, wydanej w 2014 r. Wspomnienia mieszkańców ziemi uniejowskiej z czasów okupacji to nie tylko suche fakty historyczne, ale przede wszystkim opowieści, które niczym okruchy pamięci oddają atmosferę czasów wojny, wszechobecnego strachu o życie własne i bliskich oraz codziennych starań o przetrwanie. Całość opatrzona jest aparatem naukowym, ale to nie pełne naświetlenie historii Uniejowa z czasów drugiej wojny jest celem opracowania, a ukazanie wspomnień, nasyconych subiektywnością spojrzenia, które pozwolą oddać obraz ówczesnej atmosfery i pokazać Uniejów oczami żyjących w tamtym czasie ludzi. I tym razem w przygotowanie publikacji włączyła się młodzież szkolna, której prace koordynowała nauczycielka Joanna Pawlak. Część tekstów umieszczonych w książce to właśnie efekt współpracy z młodymi ludźmi, którzy zgłębiali wiedzę historyczną poprzez samodzielne poszukiwania - w kręgu własnych rodzin czy znajomych.

$\mathrm{Na}$ rok 202 I zaplanowana jest premiera monografii Uniejów i region spycimiersko-uniejowski poprzez wieki. Będzie to już druga w dorobku towarzystwa monografia, tym razem obejmująca historię wszystkich miejscowości z terenu gminy Uniejów. Dzieło powstało pod red. prof. Jana Szymczaka i Anny Kowalskiej-Pietrzak oraz pracowników naukowych Uniwersytetu Łódzkiego (prawa autorskie zostały przeniesione na Towarzystwo Przyjaciół Uniejowa), a rozdział Samorzadowy Uniejów w latach 1990-2020, przygotowywany pod red. Marka Jabłońskiego, pokazuje trzy dekady intensywnej pracy na rzecz ziemi uniejowskiej i jej okolic. Dwutomowa monografia o objętości ponad I40o stron to wyjątkowo cenne opracowanie o charakterze naukowym, nie tylko w kontekście dorobku towarzystwa, jest to bowiem najważniejsza obecnie pozycja historyczna, opisująca kompleksowo dzieje miasta i ziemi uniejowskiej.

\section{Wnioski i zakończenie}

Trudno sobie dziś wyobrazić Uniejów bez Towarzystwa Przyjaciół Uniejowa, które działa nieprzerwalnie od trzech dekad, kierowane miłością do ziemi ojczystej, z poszanowaniem dla historii i dorobku minionych pokoleń oraz z myślą o obecnych i przyszłych mieszkańcach ziemi uniejowskiej. Jego członkowie wkładają mnóstwo pracy i zaangażowania w utrwalanie historii regionu. TPU zapisuje się w dziejach Uniejowa dzięki licznym inicjatywom, mającym na celu promocję miasta i okolic. Podjęło się trudnej misji 
dokumentowania i upowszechniania wiedzy o naszym regionie w sposób godny podziwu i naśladowania. Analiza dorobku towarzystwa, zarówno pod względem jego ilości, jak i różnorodności, pozwala stwierdzić z całą stanowczością, że cele statutowe i sposoby ich realizacji zostały wypełnione treścią w sposób właściwy, a wkład towarzystwa w dorobek kulturalny ziemi uniejowskiej jest niezaprzeczalny.

Towarzystwo Przyjaciół Uniejowa wielokrotnie było odznaczane w podziękowaniu za zasługi na rzecz kultury i rozwoju gminy. Spośród ponad pięćdziesięciu wyróżnień warto wymienić choćby kilka:

- dyplom honorowy wojewody konińskiego za osiągnięcia w upowszechnianiu kultury (1996);

- Medal Senatu RP wręczony przez senatora Jerzego Pieniążka w podziękowaniu za wkład w rozwój społeczno-kulturalny regionu łódzkiego (200I);

- złoty medal „Za Zasługi dla Miasta i Gminy Uniejów” nadany przez burmistrza miasta i gminy Uniejów (201 I);

- złoty medal „Opiekuna Miejsc Pamięci Narodowej” przyznany przez Wojewódzki Komitet Ochrony Pamięci Walk i Męczeństwa w Łodzi (20II);

- odznaka honorowa „Zasłużony dla Kultury Polskiej” przyznany Urszuli Urbaniak przez Ministra Kultury i Dziedzictwa Narodowego (2016);

- medal im. Aleksandra Patkowskiego przyznany przez Radę Krajową Ruchu Stowarzyszeń Regionalnych RP za zasługi dla idei regionalizmu (2016) ${ }^{18}$.

Sukces TPU jest niewątpliwie zasługą aktywności i zaangażowania poszczególnych członków, ale też mądrze budowanej przez prezesów i zarządy strategii rozwoju uprawomocnianej ocenami komisji rewizyjnych i ustaleniami walnych zebrań. To także efekt synergii wynikającej z umiejętnej i owocnej współpracy z władzami i ośrodkami kultury. Wszystko to sprawia, że TPU jest ważnym podmiotem, pełniącym funkcję integracyjną, który kultywuje tradycje regionu z poszanowaniem znaczenia historii, rodzinnej tradycji i kultury w życiu narodu oraz przyjmuje moralną współodpowiedzialność za ochronę i rozwój tych wartości, tak współcześnie, jak i dla potomnych.

Fakt, że kolejne pokolenia członków pragną realizować niezmiennie te same cele na przestrzeni 30 lat wydaje się być swoistym ewenementem. Dowodzi to tego, że zamiłowanie i działania na rzecz ziemi ojczystej mogą być wciąż atrakcyjne, mimo upływających lat i zmieniających się trendów.

I8 30 lat minęto - Jubileusz Towarzystwa Przyjaciót Uniejowa, „W Uniejowie” 202I, nr 85 , s. 19 . 
Niemal każdego roku TPU zyskuje w swoich szeregach kilku nowych członków, co budzi nadzieję, że działalność uniejowskich regionalistów będzie kontynuowana w przyszłości i zaowocuje wieloma interesującymi inicjatywami.

W roku jubileuszu wypada życzyć towarzystwu, aby dotychczasowa praca i zaangażowanie oraz lata nieznużonego wysiłku wkładanego w utrwalanie historii gminy - tragicznych oraz przełomowych wydarzeń, niezwykłych osób, codzienności mieszkańców - nadal były upamiętniane i zapisywane na kartach kolejnych publikacji.

Składam podziękowanie Pani Urszuli Urbaniak - prezes Towarzystwa Przyjaciół Uniejowa - za konsultacje i pomoc w przygotowaniu tego artykułu.

\section{Bibliografia}

30 lat minęto - Jubileusz Towarzystwa Przyjaciót Uniejowa, „W Uniejowie” 202I, nr 85, s. I9.

Chańko J., Życie kulturalne, [w:] J. Szymczak (red.), Uniejów. Dzieje miasta, Towarzystwo Przyjaciół Uniejowa, Łódź-Uniejów 1995, s. 370.

Kaczmarek J., Drodzy Przyjaciele..., [w:] 25 lat Towarzystwa Przyjaciót Uniejowa I9gI-20I6, s. 4.

Lata 20II-20I5, [w:] 25 lat Towarzystwa Przyjaciót Uniejowa I99I-20I6, s. I6.

Powstanie Towarzystwa Przyjaciót Uniejowa i jego pierwsze działania, [w:] 25 lat Towarzystwa Przyjaciót Uniejowa I99I-20I6, s. 7.

Statut Towarzystwa Przyjaciót Uniejowa, art. 4, Władze i struktura organizacyjna (tekst sporządzony przez zarząd Towarzystwa Przyjaciół Uniejowa $\mathrm{z}$ uwzględnieniem zmian przyjętych podczas walnego zebrania członków w dniu I7 marca 2018 r.).

Towarzystwo Przyjaciót Uniejowa, [w:] Kronika TPU, t. I., Uniejów I990, s. 5. Tyczyno A.R., Ioo lat budowania społeczeństwa obywatelskiego na Ziemi Uniejowskiej, Urząd Miasta w Uniejowie, Uniejów 2013, s. 89.

\section{Źródła internetowe}

Poradnik-przywileje OPP, [online] http://www.poradnik.ngo.pl/przywilejeopp [dostęp: 10.05.202I].

Towarzystwo Przyjaciót Uniejowa, [online] http://www.rejestr.io/krs/250380/ towarzystwo-przyjaciol-uniejow [dostęp: I0.05.202I]. 
Urbaniak U., Izba Regionalna Ziemi Uniejowskiej, [online] Towarzystwo Przyjaciół Uniejowa https://archiwa.org [dostęp: I0.05.202I].

\section{Society of Friends of Uniejów - 30 years of activity}

SU M M A RY | In 202I it is 30 years since the Society of Friends of Uniejów (TPU) was set up. All this time it has been active in many fields, conducting social and cultural activity in Uniejów municipality. This article presents the circumstances in which TPU was established, its organizational structure and major facts from its history. It also highlights the main directions of its activity over the past 30 years and its major achievements. The numerous initiatives undertaken by TPU have contributed significantly to the enhancement of the social and cultural life of the inhabitants of Uniejów municipality and help to commemorate the changing image of this town.

K E Y W O R D S | culture, local community, Society of Friends of Uniejów, Uniejów | Informacje o artykule: przyjęto - 24 maja 2021; zaakceptowano I6 czerwca 202I 